\title{
PENGEMBANGAN MODEL PEMBELAJARAN PEMERANAN BERORIENTASI TEKNIK CS PADA TEATER TRADISI
}

\author{
Moh.Mujib Alfirdaus \\ STKW Surabaya \\ m.mujibalfirdaus@yahoo.com
}

\begin{abstract}
Abstrak
Pengembangan Model Pembelajaran Pemeranan Berorientasi Teknik CS Pada Teater Tradisi ini merupakan upaya penulis dalam mengembangkan pembelajaran pemeranan pada teater tradisi melalui teknik peran Connstantin Stanislavsky, meskipun kebutuhan pertunjukan teater tradisi dan teater realisme konvensional berbeda. Selama ini metode pemeranan dalam teater tradisi masih bersifat spontanitas, akan tetapi metode pemeranan pada teater tradisi haruslah terukur dan bisa dipelajari pada ranah akademisi,untuk itu penulis mengembangkan metode pemeranan berorientasi pada teknik CS sebagai bahan acuan dalam pembelajaran pemeranan.. Seorang aktor adalah murid bagi alam dan murid bagi siapa saja selama ilmu yang diserapnya berguna untuk mewujudkan kreatif aktingnya. Oleh sebab itu metode CS ini menjadi sangat berpengaruh untuk melatih kecerdasan seorang aktor berakting, meskipun kebutuhannya untuk teater tradisi. Mengapa metode CS menjadi penting untuk dipelajari oleh calon aktor? Sebab analisis yang digunakan oleh metode CS masih sangat logis dan bisa dinalar, dan tidak menutup kemungkinan memberikan efek kecerdasan bagi siapa saja yang menerapkannya. Hal inilah yang kemudian yang mendasari mengapa pentingnya Pengembangan Model Pembelajaran Pemeranan Berorientasi Teknik CS Pada Teater Tradisi. Agar calon aktor yang akan bermain untuk pertunjukan tradisi maupun modern, diharapkan sudah siap dengan segala perangkat akting yang akan dimainkannya. Oleh sebab itu metode pelatihan CS, perlu diterapkan khususnya di STKW Surabaya. Tujuan penelitian pengembangan model pembelajaran pemeranan berorientasi teknik CS ini dilakukan untuk mengembangkan model pembelajaran pemeranan pada teater tradisi. Berdasarkan pengembangan yang dilakukan dalam penelitian ini dihasilkan produk, yakni Pertama berupa buku modul pembelajaran pemeranan berorientasi teknik CS pada teater tradisi. Buku modul pemeblajaran sebagai produk penelitian akan dapat membantu mahasiswa dalam menerapkan pemeranan. Produk kedua berupa buku dosen sebagai pegangan dalam proses pembelajaran yang efektif dan efisien.
\end{abstract}

Kata Kunci: Pemeranan,Teknik CS,Teater tradisi.

PENDAHULUAN

Jurusan teater Sekolah Tinggi

Kesenian Wilwatikta Surabaya pada pembelajaran mata kuliah pemeranan tradisi adalah modal utama untuk seorang aktor dalam melakukan pementasan, karena dalam teater tradisi khususnya Jawa Timuran adalah lebih dekat pada pertunjukan teater rakyat. Teater tradisi Jawa Timuran seperti 
ludruk. Dalam pertunjukan teater rakyat seperti Ludruk, seorang pemain atau aktor mempunyai daya spontanitas yang cukup tinggi. Pemain selalu berimprovisasi, artinya seorang aktor di dalam pertunjukan ludruk ketika melakukan sebuah pementasan tidak melakukan persiapan khusus seperti yang dilakukan pada teater modern. Di teater modern seorang aktor harus membaca dan menghafal naskah dulu kemudian latihan, sedangkan pada pertunjukan Ludruk seorang pemain cukup mengetahui garis besar cerita dan alurnya.

Seni pertunjukan Indonesia khususnya teater tradisi memiliki akar yang kuat pada wilayah spontanitas yaitu, seorang aktor atau pemain mempunyai daya yang kuat dalam melakukan kreatifitas secara langsung ketika dalam penciptaan pemanggungan. Dalam pemanggungan yang dilakukan oleh kelompokkelompok tradisi, cerita tidak dituliskan dalam bentuk naskah melainkan mereka cukup menyepakati tema atau plot pada cerita dan peranan karakter masingmasing pemain yang akan dipentaskan dihadapan penonton. Adapun isi, pengembangan dialog, pengembangan emosi, watak dalam peran hingga penyelesaian cerita diserahkan sepenuhnya pada kecerdasan intuisi (kreativitas) atau daya cipta pemain secara spontan di atas panggung. Inilah yang kemudian dalam teater tradisi seorang pemain dalam mementaskan sebuah pertunjukan atau cerita mamiliki ketrampilan untuk improvisasi. Jadi dalam sebuah teater tradisi seorang pemain atau aktor lebih mengutamakan aktivitas murni diatas panggung yang biasanya disebut spontanitas.

Selama ini pembelajaran yang dilakukan oleh jurusan teater STKW terkait dengan mata kuliah pemeranan tradisi masih menggunakan pembelajaran praktek improvisasi secara langsung dan belum menggunakan metode atau teknik pemeranan. Improvisasi dalam teater tradisi sangat diperlukan maka harus dipelajari, karena improvisasi dalam tradisi tidak dijadikan ilmu maka dalam pembelajaranya harus menggunakan konsep atau metode pemeranan dalam improvisasi. Pada penelitian ini akan dikembangkan metode pembelajaran pemeranan dari metode pemeranan Constantin Stanislavsky.

Pengembangan

Model

Pembelajaran Pemeranan Berorientasi Teknik CS Pada Teater Tradisi adalah salah satu eksplorasi yang penulis lakukan bersama tim, meskipun kebutuhan pertunjukan teater tradisi dan teater realisme konvensional berbeda, akan tetapi metode pemeranan yang harus dikuasai oleh aktor tidak ada yang berbeda. Seorang aktor adalah murid bagi alam dan murid bagi siapa saja selama ilmu yang diserapnya berguna untuk mewujudkan kreatif 
aktingnya. Oleh sebab itu metode CS ini menjadi sangat berpengaruh untuk melatih kecerdasan seorang aktor berakting, meskipun kebutuhannya untuk teater tradisi. Mengapa metode CS menjadi penting untuk dipelajari oleh calon aktor? Sebab analisis yang digunakan oleh metode CS masih sangat logis dan bisa dinalar, dan tidak menutup kemungkinan memberikan efek kecerdasan bagi siapa saja yang menerapkannya.

Meskipun di dalam teater tradisi terkadang akting para aktor tidak dituntut terlalu serius dalam penyikapannya seperti dalam teater realisme konvensional, tapi seorang aktor teater tradisi di tuntut untuk lebih fleksibel, karena tidak semua peran dalam tampilan teater tradisi juga harus melucu semua, bahkan dalam pengadeganan teater tradisi biasanya sudah ada pembagian tokoh yang serius dan menjiwai perasaan peran yang akan dihidupkannya, begitu juga dengan pelawak yang kehadirannya terkadang untuk mencairkan suasana dan menjadi pelayan para pangeran atau raja.

Untuk para pelawak akhirnya akan membantu apabila tetap mempelajari metode pemeranan CS, sebab seorang pelawak juga sudah seharusnya mengerti akan menghidupkan tokoh yang melawak, bukan hanya memainkan diri sendiri dengan segala keegoan ketika berperan, sibuk mencari perhatian penonton, bahkan tidak menutup kemungkinan seperti haus akan pujian lucu dari penonton, akhirnya jika bermain berdua over akting tidak terhindarkan. Dalam teater tradisi memang sah-sah saja over akting, tetapi alangkah baiknya apabila menghidupkan tokoh dengan melawak, maka peran yang proporsional akan lebih mudah di dapatkan dari pada yang hanya mengandalkan kelucuan yang dipaksakan dari diri sendiri. Hal inilah yang kemudian yang mendasari mengapa pentingnya Pengembangan Model Pembelajaran Pemeranan Berorientasi Teknik CS Pada Teater Tradisi. Agar calon aktor yang akan bermain untuk pertunjukan tradisi maupun modern, diharapkan sudah siap dengan segala perangkat akting yang akan dimainkannya.

\section{METODE PENELITIN}

Pendekatan yang digunakan dalam penelitian ini adalah Educational research and Development $(R \mathcal{E} D)$ yang digunakan utuk menghasilkan produk tertentu dan menguji keefektifan produk tersebut menurut Borg \& Gall (2005). Langkah Borg \& Gall dipilih dengan pertimbangan lebih jelas dan mudah dilaksanakan. Secara garis besar penelitian ini ada tiga tahap, yaitu penelitian pendahuluan atau pengkajian masalah, tahap pengembangan, dan tahap uji coba sekaligus revisi. 


\section{HASIL DAN PEMBAHASAN}

\section{A. Teknik CS}

\section{Ujian Pertama}

Metode ini adalah salah satu cara seorang guru atau sutradara membantu aktor dan murid mewujudkan obsesinya untuk bermain seni peran, sebab peran yang sesuai dengan kemauan aktor itu sendiri, akan lebih baik hasilnya apa bila ia mewujudkannya dengan cara bersungguh-sungguh, karena semakin seorang aktor mencintai perannya maka akan semakin mudah ia menghidupkan lahir dan bathinnya tokoh yang akan ia perankan, sebab ada rasa senang dan bahagia dalam mengeksplorasi kebutuhan tokoh tersebut. Sebagai latihan pertama aktor diberi kesempatan untuk memainkan nukilan lakon yang telah dipilih sendiri. Latihan ini gunanya untuk melihat seorang aktor berada di depan dekor, dirias, mengenakan kostum, dan hal teknis lainnya yang mengundang aktor untuk menghidupkan tokoh yang akan dimainkannya. Latihan ini juga bertujuan untuk menilai kesanggupan dramatik para actor, dan juga bertujuan pada bagaimana seorang aktor mampu menafsir tokoh yang akan diperankannya yang tentu saja disesuaikan dengan segala perangkat yang membuat ia berbeda dari dirinya pribadi, supaya seorang aktor diharapkan bisa menjadi sosok atau tokoh yang akan di perankannya. Latihan seperti ini sangat membutuhkan eksplorasi dari seorang aktor untuk menemukan tokohnya, bahkan jika bisa, sampai kegerakan yang lebih kecil atau paling kecil sekalipun, tentu saja dalam prosesnya membutuhkan improvisasi, agar seorang aktor tidak terlalu lama tinggal disuatu titik dan mengulangi dengan tidak putus-putus sesuatu yang sudah di kenal (Sani, 2007: 5).

\section{Jika Berperan Sebuah Seni}

Stanislavski mengatakan bahwa "yang terpenting, carilah yang terindah di dalam seni dan coba pahami". Dalam penciptaan peran yang dilakukan seorang aktor, tentu saja banyak hal yang bisa diciptakan sebagai sebuah seni, baik itu, dialog, gestur, mimik, gerakan kecil yang membantu akting aktor, dan penghayatan. Tentu saja hal ini bisa didapatkan apa bila seorang aktor bisa berperan secara intuisi dengan bawah sadar. Aktor bermain menghidupkan lakon dan melepaskan diri dari keinginannya sendiri, ia menghayati peranan, menyadari bagaimana perasaannya dan tidak hanya memikirkan apa yang harus ia perbuat di atas panggung, sebab hal teknis sudah selesai saat latihan, dan ketika di pentaskan harus tampak mengalir, bahkan penonton menyaksikan pementasan seperti melihat atau mengintip kehidupan realita.

\section{Motivasi}

Sebagai seorang aktor di atas panggung, tentu saja harus menyadari, bahwa apapun yang terjadi di atas 
panggung hendaklah memiliki suatu tujuan yaitu, suatu tujuan khusus, bukan hanya sekedar di lihat oleh penonton, sebab di dalam kehidupan manusia juga hidup berdasarkan tujuan-tujuan tertentu, begitu pulalah hendaknya kehidupan tokoh di atas panggung yang dihidupkan oleh sang aktor. Oleh sebab itu seorang aktor sebaiknya bisa berperan secara lahir dan bathin, baik itu tindakan, ucapan maupun mengungkapkan perasaan, karena hal ini telah mengalir seiring dengan alam sadar dan bawah sadar manusia, itulah mengapa bahwa proses latihan dan eksplorasi menjadi penting, bukan hanya untuk kebutuhan teater modern, di teater tradisi hal ini juga menjadi penting.

\section{Imajinasi}

Seni tidak bisa dipungkiri adalah hasil dari imajinasi, begitu juga dengan karya seorang pengarang drama, oleh sebab itu tujuan seorang aktor adalah mempergunakan tekniknya untuk merobah lakon menjadi aktualitas teater (Sani, 2007: 53). Selain imajinasi seorang seniman juga dituntut menciptakan fantasi. Bedanya ialah imajinasi menciptakan hal yang mungkin ada atau terjadi, sedangkan fantasi membuat hal yang tidak ada atau tidak pernah ada dan tidak akan pernah ada. Dalam pengaplikasiannya tentu saja diharapkan seorang aktor menciptakan imajinasi dengan suatu tujuan yang jelas. Kekuatan imajinasi ini pula yang akan memberikan keindahan permainan seorang aktor di atas panggung, dan hasil imajinasi ini pula yang akan dikenali atau ditandai oleh penonton.

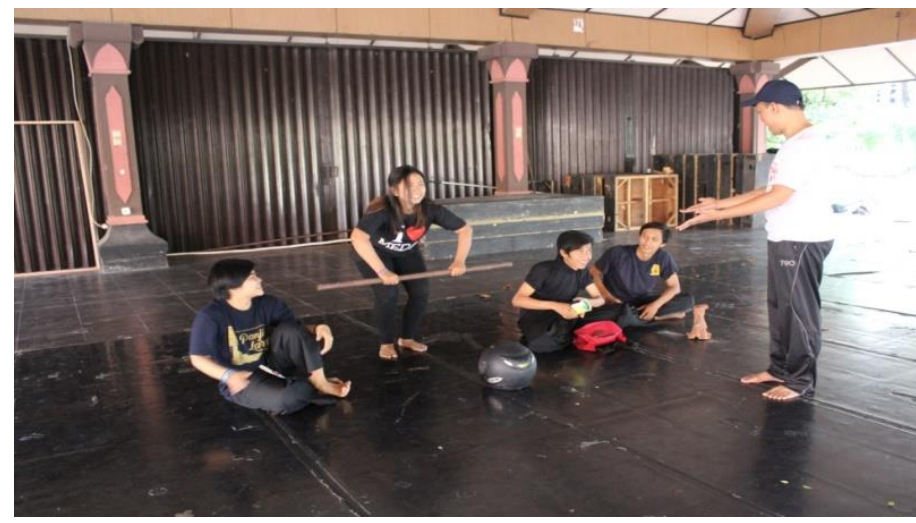

Gambar1. Latihan Teknik CS Imajinasi

\section{Konsentrasi/Pemusatan Pikiran}

Semua profesi di dunia ini tentu saja membutuhkan yang namanya konsentrasi atau pemusatan perhatian, dengan harapan agar pekerjaan yang dilakukan bisa menghasilkan sesuatu yang "ideal" utuh dan sesuai dengan apa yang diharapkan. Begitu juga dengan seorang aktor yang hendaknya bisa menguasai konsentrasinya saat memainkan perannya di atas panggung. Sebab bila konsentrasi ini tidak terjaga, 
maka bisa dipastikan konsentrasi kehilangan auranya. Salah satu celah penonton juga akan ikut hancur untuk mengetahui seorang aktor menyaksikannya, keindahan konsentrasi atau tidak dengan peran pementasan realis tidak lagi bisa dirasa, yang ia mainkan, adalah dengan melihat sebab aktor telah kehilangan bangunan matanya. konsentrasinya, pertunjukan akan

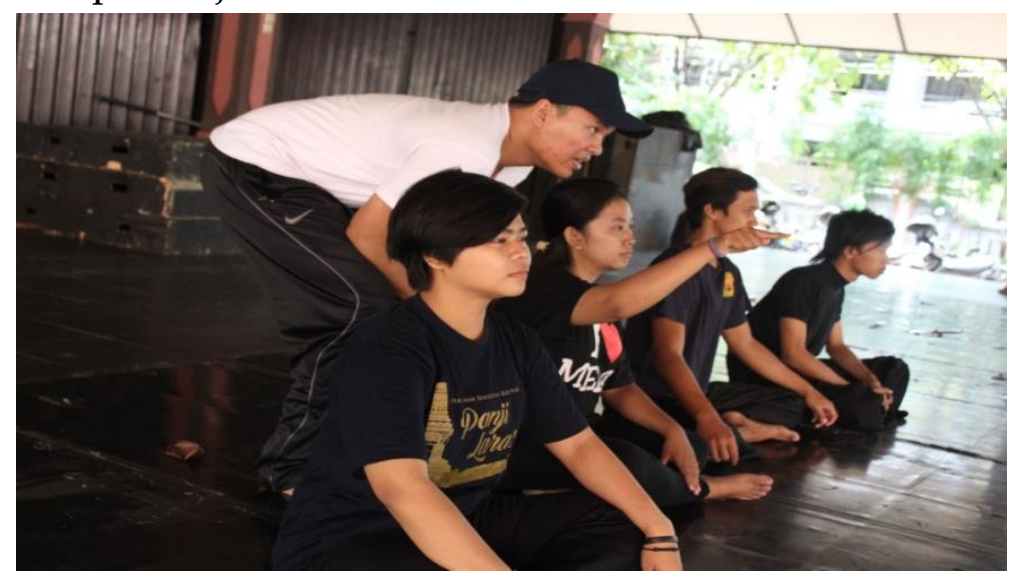

Gambar.2.Latihan Teknik CS Konsentrasi

6.Mengendurkan Urat.

Mengendurkan urat saat berperan ialah untuk menghindari ketegangan seorang aktor yang dapat membuat ia bermain tidak wajar dan tidak lues, inilah yang dikatakan dengan relax, sebab seorang aktor yang berperan di atas panggung diharapkan bisa rileks tanpa merasa ada beban di dalam dirinya. Tentu saja pengenduruan urat ini berlaku tidak hanya di atas panggung, tapi juga dalam kehidupan sehari-hari, agar hidup tidak tegang dan berfikirpun bisa lebih cemerlang. Ketegangan urat saat berperan akan menyebabkan seorang aktor kehilangan kendali dalam memainkan perannya, logika ini juga bisa dipraktekkan dalam kehidupan sehari-hari, bahwa tidak ada masalah yang bisa diselesaikan dengan ketegangan dan kekakuan di dalam diri manusia, oleh sebab itu manusia butuh rileks dan tenang dalam menghadapi segala apapun.

7.Mengendurkan Urat.

Satuan dan sasaran adalah metode teknis yang harus dipahami oleh seorang aktor, tujuannya adalah agar aktor mengerti akan alur permainan yang ia hadirkan. Sebab naskah drama memiliki bagian-bagian tertentu yang akan dimainkan oleh seorang aktor, misalnya ketika adegan muncul pertama di atas panggung, menyapa lawan main, berganti pakaian, masuk lagi dll. Peristiwa tersebut adalah suatu satuan yang ada di atas panggung, atau satuan yang sudah diciptakan oleh pengarang drama. Eksekusinya tentu saja ada pada sang aktor, apakah hendak diberi isi dalam satuan tersebut, yang kemudian 
ditambahkan dengan penemuan imajinasi.

8.Ingatan Emosi.

Ingatan emosi adalah suatu metode yang dilatihkan oleh Stanislavski untuk mewujudkan pengayaan bathin aktor dalam berperan. Capaian yang diharapkan dari ingatan emosi ini adalah memunculkan rasa dalam peran, bagaimana seorang aktor bisa memberikan impuls peran yang ia mainkan, sehingga terwujud yang namanya dorongan dari dalam, setidaknya tokoh yang diperankan tidak kering akan perasaan, tidak hanya berkutat pada wilayah teknis, melainkan memiliki rasa, karena rasa tersebut diundang melaluai ingatan emosi. Permainan tidak lagi kosong dan hampa, tapi justru berisi dan dalam setiap berakting ia kembali menjadi sebuah adegan baru yang hidup.

\section{B. Hasil Pengembangan}

Setelah penelitian pendahuluan dilaksanakan dan hasilnya berupa rancangan model pembelajaran, selanjutnya membuat tahap pengembangan produk utama yang berupa buku ajar pembelajaran keaktoran dengan teknik CS yang kemudian juga dikembangkan sintakssintaks pada teknik CS. Selain itu, pada langkah ini dikembangkan juga instrumen penelitian yang telah dirancang guna kebutuhan langkah penelitian berikutnya.
Beberapa prinsip yang terkait dengan produk utama adalah sintaks pembelajaran dan perangkat pembelajaranya dapat dijelaskan sebagai berikut:

a. Buku Ajar dalam pembelajaran berupa sintaks-sintaks pembelajaran keaktoran berorientasi pada teknik CS yang dijabarkan dalam materi ajar, kegiatan mahasiswa, tes mandiri dan latihan yang diperuntukkan pada mahasiswa jurusan teater semester satu STKW Surabaya.

b. Buku Dosen berupa perangkat pembelajaran mulai dari Silabus dengan jumlah 1 SK dan 4 KD yang selanjutnya dijabarkan dalam setiap Rancangan

Pelaksanaan Pembelajaran (RPP), Penjabaran Materi, kisi-kisi tes pengetahuan, keterampilan, dan penilaian.

c. Instrumen Penelitian berupa seperangkat instrumen yang digunakan untuk mengukur tingkat kesahihan (valid), keefektifan dan kepraktisan model beserta perangkatnya.

Dibawah ini merupakan penjelasan secara terperinci karakteristik kedua produk yang dihasilkan dalam penelitian pengembangan ini.

\section{a. Buku Ajar Pembelajaran}

Buku Ajar Pembelajaran ini merupakan sintaks-sintaks yang merujuk pada teori pemeranan Constantin Stanislasvk, pada teori 
tersebut digunakan untuk menyusun langkah kegiatan pembelajaran pemeranan. Ada sepuluh sintaks yang digunakan, kesepuluh sintaks tersebut telah dijelaskan pada tabel 4.5. BukuA ajar yang telah dikembangkan berisi uraian materi yang harus dikuasai oleh mahasiswa dan dilengkapi dengan contoh-contoh, tes mandiri, tugas dan latihan untuk mengukur aspek pengetahuan dan keterampilan yang di gabungkan dengan LKM. Untuk lebih memperjelas langkah kegiatan pembelajaran pemeranan dengan teknik CS, secara garis besar hasil perencanaan dari buku Ajar dapat dilihat dilampiran produk pengembangan. Buku Ajar terdiri dari delapan bab yang disusun berdasarkan SK-KD, meliputi:
a. Bab I : Pendahuluan
b. Bab II : Pengertian Drama dan

Teater

c. Bab III : Konsentrasi

d. Bab IV : Motivasi

e. Bab V : Imajinasi

f. Bab VI : Ingatan emosi

g. Bab VII : Adaptasi

h. Bab VIII : Rasa Keyakinan dan Kebenaran

$\begin{array}{ll}\begin{array}{l}\text { i. Bab IX } \\ \text { apapun }\end{array} & \text { : Respon Aktor terhadap } \\ \text { j. Bab X } & \text { : Kreativitas Batiniah } \\ \text { k. Bab XI } & \text { : Garis yang tak terputus } \\ \text { l. Bab XII } & \text { : Jika Berperan itu sebuah } \\ \text { seni } & \\ \text { m.Bab XIII } & \text { : Evaluasi } \\ \text { n. Bab XIV } & \text { : Penutup }\end{array}$

Pada bab tiga sampai bab dua belas dijelaskan uraian materi, langkah pembelajaran, rangkuman, tes mandiri, dan LKM. Bahan ajar secara terperinci dapat dilihat pada lampiran produk pengembangan penelitian.

\section{b. Buku Dosen}

Buku Dosen ini berisikan beberapa desain pembelajaran yang dijadikan acuan oleh dosen dalam melaksanakan kegiatan pembelajaran pemeranan diperkuliahan. Adapun isi dari buku dosen dijelaskan dibawah ini:

1) Silabus

Silabus merupakan perangkat pembelajaran yang digunakan dosen dalam berisikan desain pembelajaran dalam satu semester. Silabus dibuat sebagai acuan untuk merancang kegiatan pembelajaran dalam setiap pertemuan. Silabus pembelajaran pemeranan teknik CS ini terdiri dari satu SK dan empat KD. Adapun secara rinci silabus dapat dilihat pada lampiran dan buku dosen, sedangkan untuk penjelasan secara garis besar disajikan dibawah ini:

2). RPP

\section{Rencana}

Pelaksanaan

Pembelajaran merupakan program perencanaan yang disusun sebagai pedoman pelaksanaan pembelajaran untuk setiap proses pembelajaran. RPP yang dibuat pada pembelajaran pemeranan dengan teknik CS merupakan pengembangan dari silabus. Komponen yang ada dalam RPP sama 
dengan yang disilabus, tetapi dalam RPP rincianya lebih detail dalam merencanakan kegiatan pembelajaran pemeranan dalam setiap pertemuan. Jumlah pertemuan dalam pembelajaran pemeranan dengan teknik CS adalah 16 pertemuan dengan bobot mata kuliah 2 sks. Secara lengkap dan terperinci RPP dapat dilihat dan dibaca pada lampiran produk pengembangan.

3). Kisi- Kisi Hasil Belajar.

Kisi-kisi hasil belajar merupakan jawaban dari soal-soal yang ada pada buku modul. Soal-soal tersebut dijadikan sebagai bentuk latihan mandiri sekaligus dipadukan dengan tugas-tugas mahasiswa yang ada dalam LKM. Bentuk soal yang ada pada buku ajar ada dua aspek, yaitu pengetahuan dan keterampilan. Soal dibuat berdasarkan indikator yang terdapat dalam setiap kompetensi. Kisi-kisi yang ada pada buku dosen ada dua aspek yaitu kisi-kisi tes hasil belajar pengetahuan dan kisikisi tes hasil keterampilan. Secara rinci kisi-kisi dapat dibaca pada lampiran produk pengembangan.

4). Pedoman Penilaian

Pedoman penilaian merupakan petunjuk cara melaksanakan penilaian pada tes mandiri dan tugas-tugas yang memiliki dua aspek, yaitu penilaian pengetahuan dan penilaian keterampilan. Didalam pedoman penilaian, cara penilaianya yang ada pada pengetahuan berbeda dengan penilaian keterampilan. Pada aspek pengetahuan cara penelaian dengan menggunakan tes soal, sedangkan dalam aspek keterampilan cara penilaiannya dengan pengamatan yang telah disesuaikan dengan rubrik penilaian. Format penghitungan nilai pada aspek pengetahuan dan keterampilan sama yaitu: Nilai : $\frac{\text { Jumlah skor }}{\text { skor maksimal }} \times 100=$.

\section{SIMPULAN}

Pada dasamya penelitian pengembangan ini telah menghasilkan model pembelajaran, yaitu buku ajar pembelajaran pemeranan berorientasi teknik CS. Pengembangan model pembelajaran ini sekaligus menghasilkan perangkat pembelajaran yang sesuai untuk melaksanakan buku ajar. Hasil ini sesuai dengan tujuan pengembangan yang telah dirumuskan dalam Bab I, yaitu memperoleh model pemebelajaran pemeranan berorientasi teknik CS yang sahih, praktis, dan efektif.

\section{DAFTAR PUSTAKA}

Anirun,Suyatna. 1998. Menjadi Aktor. Bandung : Studi Teater Bandung bekerjasama dengan Taman Budaya Jawa Barat Dan PT Rekamedia Multiprakarsa.

Anwar,Chairul. 2005. Drama Bentuk Gaya dan Aliran, Yohyakarta : Elkaphi Bolelavsky, Richard. 1949. Acting: The First Six lesson. New York : Published by Theatre Arts Books. 
Borg, W.R \& Gall, R.D. 2005. Educational Reasearch: An Introduction. Boston: Person.

Stanislavski,Constantin.2008.Membangu $n$ Tokoh.Jakarta;KPG

Cohen,Robert. 1983. Theatre Brief Edition, California : Mayfield Publishing Company.

Depdiknas. 2008. Panduan Pengembangan Bahan Ajar, Jakarta Textbook writing: Dasar-Dasar Pemahaman, Penulisan dan Pemakaian Buku Ajar: Yogyakarta:Ar-ruzz Media. El saptaria, Rikrik. 2006. Panduan Praktis Acting untuk Film dan Teater Acting Handbook, Bandung, Rekayasa Sains.

Harymawan,RMA. 1998. Dramaturgi, bandung: CVRosda.

J.waluyo,Herman.2001. Drama (Teori dan Pengajaranya). Yogyakarta : PT Manindita Graha Widya.

Miiter, Shomit, 2002. Stanilavsky,Brecht, Grotowsky,Broo $k$, system pelatihan lakon, Yogyakarta: MSPI

Prastowo, Andi. 2011. Panduan Kreatif Membuat Bahan Ajar Inovatif. Jogjakarta : DIVA Press.

Subandiyah, Heny. 2012. Pengembangan Model Pembelajaran Apresiasi Sastra Berdasarkan Teori Respon Pembaca dan Sistem Among, Disertasi tidak diterbitkan

Sugiyono. 2011. Metode penelitian kuantitatif kualitatif dan $R \mathcal{E} D$. Bandung: Alfabeta
Sumardjo, jakob. 1997. Perkembangan Teater Dan Drama Indonesia .Bandung : STSI PRESS

Trianto. 2011. Mendesain Model Pembelajaran Inovatif-Progresif, Jakarta : Kencana Prenada Media Group.

Satoto, Soediro. 2012. Analisi Drama dan Teater, Yogyakarta : penerbit Ombak.

Sugiyono. 2011. Metode Penelitian Pendidikan (Pendekatan Kuantitatif, Kualitatif dan RED). Bandung : Alfabeta 